\title{
Measuring methods for groundwater - surface water interactions: a review
}

\author{
E. Kalbus, F. Reinstorf, and M. Schirmer \\ UFZ - Centre for Environmental Research Leipzig-Halle in the Helmholtz Association, Department of Hydrogeology, \\ Permoserstr. 15, 04318 Leipzig, Germany
}

Received: 9 May 2006 - Published in Hydrol. Earth Syst. Sci. Discuss.: 21 July 2006

Revised: 16 October 2006 - Accepted: 11 November 2006 - Published: 21 November 2006

\begin{abstract}
Interactions between groundwater and surface water play a fundamental role in the functioning of riparian ecosystems. In the context of sustainable river basin management it is crucial to understand and quantify exchange processes between groundwater and surface water. Numerous well-known methods exist for parameter estimation and process identification in aquifers and surface waters. Only in recent years has the transition zone become a subject of major research interest; thus, the need has evolved for appropriate methods applicable in this zone. This article provides an overview of the methods that are currently applied and described in the literature for estimating fluxes at the groundwater - surface water interface. Considerations for choosing appropriate methods are given including spatial and temporal scales, uncertainties, and limitations in application. It is concluded that a multi-scale approach combining multiple measuring methods may considerably constrain estimates of fluxes between groundwater and surface water.
\end{abstract}

\section{Introduction}

Surface water and groundwater have long been considered separate entities, and have been investigated individually. Chemical, biological and physical properties of surface water and groundwater are indeed different. In the transition zone a variety of processes occur, leading to transport, degradation, transformation, precipitation, or sorption of substances. Water exchange between groundwater and surface water may have a significant impact on the water quality of either of these hydrological zones. The transition zone plays a critical role in the mediation of interactions between groundwater and surface water. It is characterized by permeable sediments, saturated conditions, and low flow velocities,

Correspondence to: E. Kalbus

(edda.kalbus@ufz.de) thus resembling the characteristics of terrestrial aquifers. In streams, however, the zone may contain some proportion of surface water due to the infiltration of stream water into the pore space, conferring on it features of the surface water zone as well. Ecologists have termed this area the hyporheic zone (Schwoerbel, 1961) and highlighted the significance of exchange processes for the biota and metabolism of streams (Hynes, 1983; Brunke and Gonser, 1997). For the protection of water resources it is crucial to understand and quantify exchange processes and pathways between groundwater and surface water. Particularly in case of contamination, it is fundamental to know the mass flow rates between groundwater and surface water for the implementation of restoration measures. Woessner (2000) stressed the need for hydrogeologists to extend their focus and investigate near-channel and in-channel water exchange, especially in the context of riparian management.

Interactions between groundwater and surface water basically proceed in two ways: groundwater flows through the streambed into the stream (gaining stream), and stream water infiltrates through the sediments into the groundwater (losing stream). Often, a stream is gaining in some reaches and losing in other reaches. The direction of the exchange flow depends on the hydraulic head. In gaining reaches, the elevation of the groundwater table is higher than the elevation of the stream stage. Conversely, in losing reaches the elevation of the groundwater table is lower than the elevation of the stream stage. A special case of losing streams is the disconnected stream, where the groundwater table is below the streambed and the stream is disconnected from the groundwater system by an unsaturated zone. Seasonal variations in precipitation patterns as well as single precipitation events can alter groundwater tables and stream stages and thereby cause changes in the direction of exchange flows. On a smaller scale, water flow into and out of the streambed may be induced by pressure variations on the streambed caused by geomorphological features such as pool-riffle sequences,

Published by Copernicus GmbH on behalf of the European Geosciences Union. 
discontinuities in slope, or obstacles on the streambed (Thibodeaux and Boyle, 1987; Savant et al., 1987; Hutchinson and Webster, 1998). Also, a relocation of sediment grains on the streambed may lead to a trapping of stream water in the sediment interstices and a release of interstitial water to the stream (Elliott and Brooks, 1997). The interactions, however, are complex. Sophocleous (2002) presented a comprehensive outline of the principal controls and mechanisms of groundwater - surface water exchange.

Hydrogeologists and surface water hydrologists traditionally have approached the interface between groundwater and surface water from their particular perspective. In the literature a variety of techniques to identify and quantify exchange flows are described which originate from the respective disciplines of water research. Our aim was to bring together these different perspectives and approaches in order to study the stream-aquifer system as a whole. The range of available techniques to determine interactions between groundwater and surface water is broad. Depending on the study purpose, methods have to be chosen which are appropriate for the respective spatial and temporal scale. If processes or flow paths are the study focus, other methods are needed than for the quantification of regional groundwater flow to develop management schemes. Numerical modelling, which is an indispensable tool for watershed management, relies on the determination of parameters representing the flow conditions for the selected model scale. Thus, the proper choice of methods is critical for the usefulness of measurement results. As Sophocleous (2002) pointed out, the determination of water fluxes between groundwater and surface water is still a major challenge due to heterogeneities and the problem of integrating measurements at various scales.

Scanlon et al. (2002) presented an overview of techniques for quantifying groundwater recharge on different space and time scales. Some of these methods can equally be applied to measure groundwater discharge to streams and recharge through the streambed. Landon et al. (2001) compared instream methods for measuring hydraulic conductivity aiming at determining the most appropriate techniques for use in sandy streambeds.

The purpose of this paper is to provide an overview of the methods that are currently state-of-the-art for measuring interactions between groundwater and surface water. The focus is on the estimation of water fluxes at the stream-aquifer interface. It is intended for readers starting to work on the investigation of interactions between groundwater and surface water who might have varying backgrounds in the different disciplines of hydrology. Therefore, each method is briefly described and references for further information are given. The methods are grouped into direct measurements of water flux, heat tracer methods, methods based on Darcy's Law, and mass balance approaches. Since the contamination of aquifers and streams is of growing concern worldwide, methods to determine contaminant concentrations for the estimation of contaminant mass fluxes between groundwater and stream water are also presented. With respect to the study purpose, the suitability of the different methods and their applicability on different space and time scales are discussed. Modelling approaches, such as inverse modelling to determine hydraulic conductivities, are not covered in this study. The special case of disconnected streams with an unsaturated zone between streambed and aquifer is omitted in this review and, thus, methods typically applied in the unsaturated zone are not discussed.

\section{Direct measurements of water flux}

Direct measurements of water flux across the groundwater surface water - interface can be realized by seepage meters. Bag-type seepage meters as proposed by Lee (1977) consist of a bottomless cylinder vented to a deflated plastic bag. The cylinder is turned into the sediment, and as water flows from the groundwater to the surface water, it is collected in the plastic bag. From the collected volume, the cross section area of the cylinder, and the collection period the seepage flux can be calculated. In case of surface water seeping into the sediment, a known water volume is filled into the plastic bag prior to the installation and from the volume loss the infiltration rate is calculated. These bag-type seepage meters have been used extensively in lakes, estuaries, reservoirs, and streams (e.g., Lee and Cherry, 1978; Woessner and Sullivan, 1984; Isiorho and Meyer, 1999; Landon et al., 2001).

Murdoch and Kelly (2003) discussed that, despite the simplicity of applying bag-type seepage meters, their performance is far from simple. Particularly in streams, water flowing over the collection bag may affect the hydraulic head in the bag, or may distort or fold the bag and lead to decreased or increased flux measured by the seepage meter. Libelo and MacIntyre (1994) proposed to cover the collection bag with a rigid container to isolate it from pressure gradients resulting from the movement of the stream water. Kelly and Murdoch (2003) presented a modification of a seepage meter fitted with a piezometer along the axis of the pan (a piezo-seep meter). A manometer was used to measure the difference in hydraulic head between the piezometer screen and the inside of the pan. A pump was temporarily attached to the pan and the pumping flow rate was correlated to the head differential between piezometer and pan. This permitted the estimation of fluxes into the seepage meter pan from the head differential measured under ambient conditions.

Various types of automated seepage meters have been developed that overcome problems related to the collection bags. They are based on the same principle of isolating and covering a part of the groundwater - surface water interface with a chamber open at the bottom, but abandon the use of collection bags and instead deploy instruments to continuously record the water flow rate through the outlet tube. Devices to measure the flow rate include, for instance, the heat pulse meter (Taniguchi and Fukuo, 1993; Krupa et al., 1998) 
that is based on the relationship between the travel time of a heat pulse in the flow tube and the flow velocity; the ultrasonic meter (Paulsen et al., 2001) that relates the travel time of an ultrasonic signal through the flow tube to the flow velocity; the dye-dilution meter (Sholkovitz et al., 2003) based on the principle that the rate at which a dyed solution is diluted by the inflow or outflow of water is directly proportional to the seepage flow rate; and the electromagnetic meter (Rosenberry and Morin, 2004) that measures the voltage induced by water passing through an electromagnetic field, which is proportional to the flow velocity. These modifications enable a monitoring of seepage variations with time.

Seepage meters are based on a simple concept and inexpensive to construct. They are useful for the detection of groundwater discharge or recharge zones. To obtain representative average seepage fluxes, however, measurements at many locations are required. In streams, the fluxes measured with a seepage meter might not entirely be attributed to groundwater discharge, but include shallow throughflow or hyporheic exchange flow (see Sect. 7.2). The seepage meters themselves constitute obstacles to the stream flow that might induce interstitial flow into the seepage meter pan.

\section{Heat tracer methods}

The difference in temperature between groundwater and surface water can be used to delineate groundwater discharge or recharge zones and quantify water fluxes at the groundwater - surface water interface. Groundwater temperatures are relatively stable throughout the year. In contrast, stream temperatures vary strongly on a daily and seasonal basis. Therefore, gaining reaches are characterized by relatively stable sediment temperatures and damped diurnal variations in surface water temperatures, whereas losing reaches are characterized by highly variable sediment and surface water temperatures (Winter et al., 1998). This permits an identification of the general character of the flow regime by recording temperature time series in the stream and the surrounding sediments (Constantz, 1998; Constantz and Stonestrom, 2003).

Time series of temperature profiles document the penetration of cyclic temperature changes into the streambed. Because water is heated and cooled at the surface, downward moving water causes a deeper penetration of cyclic temperature changes. Conversely, upward moving water leads to less penetration of cyclic temperature changes because the upwelling groundwater has a relatively constant temperature. The maximum and minimum temperatures of a complete cycle form a temperature envelope enclosing all measured temperature profiles. This envelope is compressed toward the streambed surface in case of upwelling groundwater. Downwelling stream water lets the envelope expand downward (Constantz and Stonestrom, 2003).

Heat transport in the subsurface is a combination of advective heat transport (i.e., heat transport by the flowing wa- ter) and conductive heat transport (i.e., heat transport by heat conduction through the solid and fluid phase of the sediment). It can be described by a heat transport equation (Domenico and Schwartz, 1998) which is analogous to the advection-dispersion equation for solute transport in groundwater. Various analytical and numerical solutions have been developed for the heat transport equation (e.g., Carslaw and Jaeger, 1959; Suzuki, 1960; Bredehoeft and Papadopolus, 1965; Stallman, 1965; Turcotte and Schubert, 1982; Silliman et al., 1995). Using these solutions, seepage rates through the streambed can be calculated from the temperature profiles measured beneath the stream (e.g., Constantz et al., 2001, 2002; Taniguchi et al., 2003; Becker et al., 2004). A popular procedure is to adjust hydraulic conductivities in a numerical model until seepage rates cause a match between measured and modelled temperatures (Stonestrom and Constantz, 2004). The thermal properties of streambed sediments are almost independent of texture and vary only little between different streambeds; hence, they can be obtained from literature values (Constantz and Stonestrom, 2003). In contrast, hydraulic properties are highly variable. Streambed temperatures are very sensitive to the hydraulic conditions, which makes heat a useful tool for the estimation of fluxes through streambed sediments.

A different approach to estimate water fluxes through the streambed using streambed temperatures was taken by Conant (2004) and Schmidt et al. (2006). They measured temperatures in the streambed at many locations within a short time period. The underlying assumption was that variations in temperature are attributed to spatial variations in water flux through the streambed and not to temporal changes during the measurement period. Conant (2004) mapped the temperatures at a certain depth in the streambed and developed an empirical relation between fluxes obtained from minipiezometer data and streambed temperatures. Schmidt et al. (2006) measured streambed temperatures simultaneously at five depths and inferred fluxes from the temperature profiles using a one-dimensional analytical solution (Bredehoeft and Papadopolus, 1965) of the heat transport equation with the average surface water temperature during the measurement period and the constant groundwater temperature as boundary conditions.

A heat balance equation was used by Becker et al. (2004) to calculate groundwater discharge from measurements of stream temperature and streamflow. They divided the stream into reaches corresponding to temperature measurement points and set up a balance equation where the stream temperature is a function of the groundwater discharge rate, the difference in stream water and groundwater temperature, streamflow, and additional heat gains and losses through the stream surface.

Temperature is a robust and relatively inexpensive parameter to measure. Measurements are quick and easy to perform, making temperature-based methods very attractive for detailed delineations of groundwater discharge or 
recharge zones with high resolutions.

For further information on the use of heat as a groundwater tracer, the reader is referred to the comprehensive review by Anderson (2005).

\section{Methods based on Darcy's Law}

Methods based on Darcy's Law generally correspond to the methods used to study groundwater movement in terrestrial aquifers. They typically require measurements of the components of the Darcy equation (Darcy, 1856):

$q=-K \frac{d h}{d l}$

where $q$ is specific discharge [L/T], $K$ is hydraulic conductivity $[\mathrm{L} / \mathrm{T}], h$ is hydraulic head $[\mathrm{L}]$ and $l$ is distance $[\mathrm{L}]$. The specific discharge has the dimensions of a velocity, or a flux, and is also known as Darcy velocity or Darcy flux. Groundwater velocity, i.e., the flow velocity between two points in the aquifer as can be observed, for instance, by tracer methods, includes the porosity of the aquifer material:

$v=\frac{q}{n}$

where $v$ is groundwater velocity [L/T], $q$ is Darcy flux [L/T] and $n$ is porosity [-]. Hence, the determination of water flux in the subsurface typically requires information on the hydraulic gradient and hydraulic conductivity, or groundwater velocity and porosity.

\subsection{Hydraulic gradient}

Measuring the water level in wells and piezometers installed in the fluvial plain is the standard method to determine hydraulic head (Freeze and Cherry, 1979). A piezometer is basically a tube or pipe that is inserted into the sediment to measure the hydraulic head at a certain point in the subsurface. The direction of local groundwater flow can be determined from the differences in hydraulic head between individual piezometers installed in groups (at least three in a triangular arrangement). In case of horizontal flow, the hydraulic gradient can be calculated from the difference in hydraulic head and the horizontal distance. For the vertical components of groundwater flow, which are particularly important to understand the interaction between groundwater and surface water, a piezometer nest may be installed, with two ore more piezometers set in the same location at different depths. The hydraulic gradient can then be calculated from the difference in hydraulic head and the vertical distance. Furthermore, vertically distributed piezometer data can be used to draw lines of equal hydraulic head for the construction of a flow field map showing the groundwater flow behaviour in the vicinity of a surface water body.

Installed directly in the streambed, piezometers deliver information whether a stream reach is gaining or losing by a comparison of piezometer and stream water level. Assuming vertical flow beneath the streambed, the hydraulic gradient is obtained from the difference of the water level in the piezometer and the stream, and the depth from the sediment surface to the centre of the piezometer screen (Freeze and Cherry, 1979). Baxter et al. (2003) described an installation technique for minipiezometers which permits obtaining a large number of measurements in gravel and cobble streambeds.

The piezometer method provides point measurements of hydraulic head. The equipment is quick and easy to install, and measurement analysis is straightforward. Therefore, this method is appropriate for small-scale applications and allows a detailed survey of the heterogeneity of flow conditions in the subsurface. Groundwater movement, however, is subject to temporal variations. Therefore, all measurements of hydraulic head at a study site should be made approximately at the same time, and the resulting contour and flow field maps are representative only of that specific time (Winter et al., 1998). Pressure transducers and data loggers installed in the piezometers or pressure probes buried in the saturated subsurface may facilitate observing temporal variations in hydraulic head.

\subsection{Hydraulic conductivity}

\subsubsection{Grain size analysis}

From the grain size distribution of a sediment sample, an estimate of hydraulic conductivity can be derived employing empirical relations between hydraulic conductivity and some statistical grain size parameters such as geometric mean, median, effective diameter, etc. (e.g., Hazen, 1892; Schlichter, 1905; Terzhagi, 1925; Beyer, 1964; Shepherd, 1989). Alyamani and Sen (1993) proposed to relate hydraulic conductivity to the initial slope and intercept of the grain size distribution curve. During the determination of grain size distribution, the sediment structure and stratification are destroyed. Hence, these relations yield a value of hydraulic conductivity that represents neither the vertical nor the horizontal hydraulic conductivity and is not representative of the true hydraulic properties of the subsurface. Grain size analysis, however, delivers information about the subsurface material and the hydraulic conductivity values can be used as a first estimation for the design of further applications such as slug and bail tests.

\subsubsection{Permeameter tests}

For laboratory permeameter tests a sediment sample is enclosed between two porous plates in a tube. In case of a constant-head test, a constant-head potential is set up and a steady discharge flows through the system. Hydraulic conductivity can be calculated following Darcy's law. In a falling-head test, the time needed for the hydraulic head to 
fall between two points is recorded. Hydraulic conductivity is calculated from the head difference, the time, and the tube and sample geometry (Hvorslev, 1951; Freeze and Cherry, 1979; Todd and Mays, 2005). Depending on the direction of flow through the sediment sample in the experiment, directional hydraulic conductivity may be obtained. It is, however, difficult to take and transport samples from streambed sediments without disturbing the packing and orientation of the sediment grains, which may influence measurement results.

To obtain the vertical hydraulic conductivity of the streambed, in situ permeameter tests can be performed using a standpipe pressed into the sediment (Hvorslev, 1951). The standpipe is open at the bottom, so that a sediment column is laterally enclosed by the pipe. The pipe is filled with water and as the water level falls, the hydraulic head in the pipe and the time is recorded at two stages (falling-head permeameter test). Hydraulic conductivity is calculated from the difference in hydraulic head, the time difference, and the length of the sediment column in the standpipe. Alternatively, the water level in the pipe is held constant by injecting water, and the measured injection rate is used for test analysis (constanthead permeameter test). Chen (2000) proposed a variation of the standpipe method to obtain hydraulic conductivities in any desired direction by using an L-shaped pipe. Using a pipe with an angle of $90^{\circ}$, horizontal hydraulic conductivity can be calculated. An L-shaped pipe with any angle greater than $90^{\circ}$ delivers hydraulic conductivity along any oblique direction.

Horizontal hydraulic conductivities of the streambed may be obtained from a constant-head injection of water through a screened piezometer (Cardenas and Zlotnik, 2003). From the test geometry, the injection rate, and the operational head, hydraulic conductivity can be calculated.

In situ permeameter tests provide point measurements of hydraulic conductivity directly in the streambed. Performance and analysis are quick and easy, so that it can be useful for a detailed survey of the heterogeneity of streambeds.

\subsubsection{Slug and bail tests}

Slug and bail tests are based on introducing/removing a known volume of water (or a solid object) into/from a well or piezometer, and as the water level recovers, the head is measured as a function of time. The hydraulic properties of the subsurface are determined following the methods of Hvorslev (1951), Cooper et al. (1967), Bouwer and Rice (1976), or Hyder et al. (1994), among others. Analysis methods for partially penetrating wells in unconfined formations are most appropriate for the estimation of streambed hydraulic conductivities (e.g., Springer et al., 1999; Landon et al., 2001; Conant, 2004). Butler (1998) provided a comprehensive summary of slug and bail test performance and analysis methods. Slug and bail tests are quick and easy to perform with inexpensive equipment. In contrast to pumping tests, only one well or piezometer is needed to perform a slug and bail test. Care has to be taken concerning sufficient well development, proper test design, and appropriate analysis procedures in order to obtain reliable results (Butler, 1998). This method provides point measurements of hydraulic conductivity, albeit the scale of measurement is slightly larger that in permeameter tests. It is appropriate for process studies or for investigating heterogeneities.

\subsubsection{Pumping tests}

A pumping test to determine hydraulic conductivity requires the existence of a pumping well and at least one observation well (piezometer) in the capture zone. The well is pumped at a constant rate and drawdown in the piezometer is measured as a function of time. The hydraulic properties of the subsurface are determined using one of several available methods, e.g. the methods of Theis (1935), Cooper and Jacob (1946), Chow (1952), Neuman (1975), or Moench (1995), among others. However, for the determination of streambed hydraulic conductivities to analyse groundwater - surface water interactions the application of pumping tests is problematic because of the boundary conditions. Kelly and Murdoch (2003) described a theoretical analysis for pumping tests in submerged aquifers assuming a constant-head boundary as upper boundary condition. The lower boundary condition can either be a no-flow boundary in case the stream is underlain by bedrock or a low-conductivity formation, or a constant-head boundary in case the stream is underlain by higher conductivity materials. Pumping tests provide hydraulic conductivity values that are averaged over a large subsurface volume. Thus, these values are more representative for the entire subsurface body than conductivities obtained by point measurements. Results are less sensitive to heterogeneities in the subsurface material and preferential flow paths. However, the installation of wells and piezometers is costly and may not be justified in all cases.

A piezo-seep meter (Kelly and Murdoch, 2003) as described in Sect. 2 may provide an alternative for pumping tests to estimate streambed hydraulic conductivities. As water is pumped from a seepage meter pan, hydraulic conductivity may be obtained from the head gradient measured at a piezometer fixed to the pan, the flow rate, and the crosssectional area of the pan. This approach yields measurements of vertical hydraulic conductivities at shallow streambed depths. Contrary to conventional pumping tests, the test radius is small. The equipment is relatively inexpensive and easy to install, permitting tests at many locations to delineate the spatial distribution of streambed hydraulic conductivities.

\subsection{Groundwater velocity}

Groundwater velocity may be estimated by introducing a conservative tracer, e.g. a dye, such as uranine, or a salt, such as calcium chloride, to a well, and recording the travel time for the tracer to arrive at a downstream observation well. The 
groundwater velocity can then be computed from the travel time and distance data (Freeze and Cherry, 1979). Because groundwater velocities are usually small, the wells need to be close together in order to obtain results in a reasonable time span. Thus, only a small portion of the flow field can be observed by this method. Furthermore, the flow direction should be precisely known, otherwise the tracer plume may miss the downstream well. Multiple downstream wells along a control plane can help to overcome this problem. Another problem arises if stratification of the subsurface leads to different travel times in different layers. In this case, the applicable average groundwater velocity in the subsurface is difficult to determine (Todd and Mays, 2005). Alternatively, a tracer dye is added to a well and mixed with the contained water (borehole dilution test). While water flows into and out of the well, the tracer concentration is measured continuously. From the tracer dilution curve, groundwater velocity can be derived. This type of tracer test is particularly useful to determine the flow velocity in the streambed assuming that flow from a well near a stream is directed exclusively towards the stream (Todd and Mays, 2005).

Both tracer methods can also be used to infer hydraulic conductivity following Darcy's Law if the hydraulic gradient and porosity are known.

On a very small scale, the flow velocity in streambed sediments may be determined using the method proposed by Mutz and Rohde (2003). A small amount of tracer dye is injected into the streambed using a syringe. After a few hours a sediment core is taken around the injection point and is deepfrozen. Dividing the frozen sediment core longitudinally uncovers the movement of the tracer plume in the sediment. The flow direction can then be observed and the flow velocity can be calculated from the distance the tracer plume has travelled and the duration of exposure. This method gives velocity estimates on a scale of a few centimetres. It requires the visibility of the tracer plume in the sediment core and is limited to use in light-coloured, fine sediments.

\subsection{Porosity}

The porosity of a sediment sample can be determined by relating the bulk mass density of the sample to the particle mass density. The bulk mass density is the oven-dried mass divided by the field volume of the sample. The particle mass density is the oven-dried mass divided by the volume of the solid particles, which can be determined by a waterdisplacement test (Freeze and Cherry, 1979).

\section{Mass balance approaches}

The underlying assumption of mass balance approaches to study groundwater - surface water interactions is that any gain or loss of surface water or any change in the properties of surface water can be related to the water source, and, therefore, the groundwater component can be identified and quantified.

\subsection{Incremental streamflow}

Measurements of streamflow discharge in successive crosssections enable the determination of groundwater - surface water exchange by computing the differences in discharge between the cross sections. Streamflow discharge can be measured by various methods, including the velocity gauging method deploying any type of current meter (Carter and Davidian, 1968), or gauging flumes (Kilpatrick and Schneider, 1983). Another option is the dilution gauging method (Kilpatrick and Cobb, 1985), where a solute tracer is injected into the stream and the tracer breakthrough curves at successive cross sections are recorded. The volumetric discharge can then be inferred from the measurements. Zellweger (1994) compared the performance of four ionic tracers to measure streamflow gain or loss in a small stream.

With the velocity gauging method, the net exchange of groundwater with stream water is captured, but it is not possible to identify inflow and outflow components of surface water exchange. Harvey and Wagner (2000) suggest a combination of the velocity gauging method and the dilution gauging method to estimate groundwater inflow and outflow simultaneously. They propose "injecting a solute tracer at the upstream of the reach, measuring stream volumetric discharge at both reach end points by the dilution gauging method, and then additionally measuring discharge at the downstream end using the velocity gauging method. Groundwater inflow rate is estimated from the difference between the dilution gauging measurements at the downstream and upstream ends of the reach (divided by the reach length). In contrast, the net groundwater exchange is estimated by the difference between the velocity gauging estimate at the downstream end of the reach and the dilution gauging estimate at the upstream end of the reach (divided by reach length). The final piece of information that is needed, the groundwater outflow rate, is estimated by subtracting the net exchange rate from the groundwater inflow rate." (Harvey and Wagner, 2000).

To estimate groundwater discharge from incremental streamflow, measurements should be performed under low flow conditions so that one can assume that any increase in streamflow is due to groundwater discharge and not due to quickflow resulting from a rainfall event. This method provides estimates of the groundwater contribution to streamflow averaged over the reach length, making it insensitive to small-scale heterogeneities. The seepage flow rates should be significantly higher than the uncertainties inherent in the measurements, which constrains the spatial resolution of the method. 


\subsection{Hydrograph separation}

An estimation of the groundwater contribution to streamflow can be realized by separating a stream hydrograph into the different runoff components, such as baseflow and quickflow (e.g., Chow, 1964; Linsley et al., 1988; Hornberger et al., 1998; Davie, 2002), and then assuming that baseflow represents groundwater discharge into the stream (e.g., Mau and Winter, 1997; Hannula et al., 2003).

The validity of the underlying assumptions of the separation techniques is critical for the performance of hydrograph separation as a tool to determine groundwater-surface water interactions (Halford and Mayer, 2000). Furthermore, in cases where drainage from bank storage, lakes or wetlands, soils, or snowpacks contributes to stream discharge, the assumption that baseflow discharge represents groundwater discharge may not hold (Halford and Mayer, 2000). The limited number of stream gauging stations constrains the resolution of this method. Results are usually averaged over long stream reaches.

\subsection{Environmental tracer methods}

Tracer-based hydrograph separation using isotopic and geochemical tracers provides information on the temporal and spatial origin of streamflow components. Stable isotopic tracers, such as stable oxygen and hydrogen isotopes, are used to distinguish rainfall event flow from pre-event flow, because rain water often has a different isotope composition than water already in the catchment (Kendall and Caldwell, 1998). Geochemical tracers, such as major chemical parameters (e.g., sodium, nitrate, silica, conductivity) and trace elements (e.g. strontium), are often used to determine the fractions of water flowing along different subsurface flowpaths (Cook and Herczeg, 2000). Generally, to separate the streamflow components, mixing models (Pinder and Jones, 1969) or diagrams (Christophersen and Hooper, 1992) based on the conservation of mass are applied. Numerous applications under different hydrological settings using various tracers have been documented (e.g., Pinder and Jones, 1969; Hooper and Shoemaker, 1986; McDonell et al., 1990; Laudon and Slaymaker, 1997; Ladouche et al., 2001; Carey and Quinton, 2005). The main drawbacks of tracer-based hydrograph separation are that event and pre-event waters are often too similar in their isotope composition and that the composition is often not constant in space or time (Genereux and Hooper, 1998).

Tracer-based hydrograph separation yields groundwater discharge rates from reach to catchment scale. On a smaller scale, the differences in concentrations of environmental tracers between groundwater and surface water can be used to identify and delineate zones of groundwater discharge or recharge, provided that the differences are sufficiently large. Stable hydrogen and oxygen isotopes are widely used, because groundwater is generally less enriched in deuterium and ${ }^{18} \mathrm{O}$ than surface water (Coplen et al., 2000; Hinkle et al., 2001; Yehdeghoa et al., 1997). Numerous other geochemical and isotopic tracers have been used to study interactions between groundwater and surface water, including alkalinity (Rodgers et al., 2004), electrical conductivity (Harvey et al., 1997), or isotopes of radon (Cook et al., 2003; Wu et al., 2004), chlorofluorocarbons (Cook et al., 2003), strontium (Negrel et al., 2003), and radium (Kraemer, 2005). For further information on the use of geochemical and isotopic tracers in catchment hydrology, the reader is referred to the books by Clark and Fritz (1997), Kendall and McDonnell (1998), or Cook and Herczeg (2000), among others. As all researchers working with environmental tracers point out, a combination of various tracers and hydrologic data yields the most reliable results.

\subsection{Solute tracer methods}

Besides dilution gauging, solute tracers are also used to study the interaction between stream water and interstitial water in the streambed sediments. The temporary detainment of stream water in the sediment voids or in any other stagnant pockets of water, such as eddies or at the lee side of obstacles, is referred to as transient storage (Bencala and Walters, 1983). It is usually studied by injecting a conservative tracer into the stream and fitting a model to the tracer breakthrough curves which yields the determination of the storage zone size and exchange rate (Runkel, 1998). Studies using solute tracers and the transient storage approach to characterize surface-subsurface water exchange have been presented by D’Angelo et al. (1993), Harvey and Bencala (1993), Morrice et al. (1997), and Hart et al. (1999), among others. However, surface storage and storage in the streambed sediments are lumped together in this approach and the identification of the actual subsurface component is often difficult (Runkel et al., 2003).

\section{Methods to determine contaminant concentrations}

\subsection{Monitoring wells}

By collecting subsurface water samples from monitoring wells or piezometers the contaminant concentration can be estimated. In order to obtain reliable results, the monitoring wells should be closely spaced along transects across the contaminant plume. Multi-level monitoring wells help in creating a three-dimensional integration of contaminant concentrations (e.g., Borden et al., 1997; Pitkin et al., 1999; Conant et al., 2004). A dense grid of monitoring wells can give very detailed information about the distribution of contaminants. However, for large study sites this method becomes impractical. 


\subsection{Passive samplers}

The accumulation of groundwater contaminants by passive samplers provides an alternative to the conventional snapshot-sampling in monitoring wells (Bopp et al., 2004). Over the past few years, this technique was extensively developed and a variety of passive sampling devices has evolved. In general, these devices can be divided into four groups: water filled devices, solvent filled devices, semipermeable membrane devices, and solid-sorbent filled devices. Contaminants are collected by diffusion and/or sorption over extended periods of time. After sampling using these devices, contaminants are removed from the receiving phases or whole samplers by solvent extraction or thermodesorption and analysed chemically (Schirmer et al., 2005). The stateof-the-art of passive sampling techniques is summarized in review articles by Namiesnik et al. (2005), Stuer-Lauridsen (2005), and Vrana et al. (2005), for example. Further developments of passive sampling devices allow a combined chemical and toxicological analysis of the samples (Bopp, 2004), and combined contaminant and water flux measurements (Hatfield et al., 2004; De Jonge and Rothenberg, 2005).

The accumulation of contaminants over an entire sampling period enables time-averaged measurements which are less sensitive to daily fluctuations. Furthermore, very low contaminant concentrations can be detected in this way. Longterm monitoring using passive samplers is time- and costefficient, since only a few field trips and sample analyses are required (Bopp et al., 2004). Transport and storage of large sample volumes is not necessary, which again reduces costs and, moreover, the risk of degradation of labile substances prior to the analysis (Kot et al., 2000). The problem of the disposal of highly contaminated purged groundwater is avoided and changes in flow regimes are circumvented, both being typical problems associated with sampling through pumping. Furthermore, volatile organic compounds, which often get lost during purging, can also be detected (Powell and Puls, 1997).

Passive samplers can be applied in the aquifer, in the surface water, or in the transition zone. Frequent changes in flow direction, however, which are often observed in the transition zone, might be problematic for the calculation of mass fluxes.

\subsection{Integral pumping tests}

The issue of heterogeneity of the contaminant distribution in the subsurface is addressed by using the integral pumping test method (Schwarz et al., 1998; Teutsch et al., 2000; Ptak et al., 2000; Bauer et al., 2004; Bayer-Raich et al., 2004). This method consists of one or more pumping wells along a control plane perpendicular to the mean groundwater flow direction. The wells are operated with a constant discharge for a time period of up to several days. During pumping, concentrations of target contaminants are measured in the pumped groundwater. From the concentration time series, the concentration distribution along the control plane and thus the presence of contaminant plumes can be determined. Furthermore, contaminant mass flow rates along the control plane and the representative average contaminant concentration in the well capture zone can be computed. The method provides integral measurements over a large subsurface volume and is, therefore, less prone to heterogeneity effects of the subsurface and the contaminant distribution than point measurements. However, the disposal of the large volumes of contaminated groundwater that is pumped out of the wells during the test can be costly. The application of integral pumping tests near streams is problematic due to the boundary conditions and the influence of pumped stream water. However, it may provide reliable estimates of the contaminant concentration in the groundwater that approaches a stream and potentially discharges to the surface water.

\subsection{Grab samples}

The contaminant concentration in the surface water can simply be determined by analysing water samples from discrete grab or bottle samples. The main drawbacks of this method are that large sample volumes are often needed when contaminants are present at only trace levels, and that only snapshots of contaminant levels at the time of sampling are provided (Vrana et al., 2005). Automated sampling systems can facilitate sample collection for long-term monitoring.

\subsection{Seepage meters}

Seepage water collected in a collection bag of a seepage meter (Lee, 1977), as described in Sect. 2, can be sampled and analysed for the contaminant concentration.

\section{Discussion}

\subsection{Measurement Scales}

Various approaches and techniques to measure the interaction between groundwater and surface water have been outlined above. The methods differ in resolution, sampled volume, and the time scales they represent. The spatial measurement scales of the different methods (Fig. 1) have to be considered for the integration of diverse measurements at a study site. Densely spaced point measurements may deliver detailed information on the heterogeneity of the measured parameter, but the reaches between the measurement locations remain unknown. Therefore, there is a risk to miss extreme values of the parameter distribution which may affect computed results. Methods that integrate over large sample volumes provide reliable estimates of average values but do not enable a detailed characterization of the spatial heterogeneity of the respective parameter. Often, the choice of 


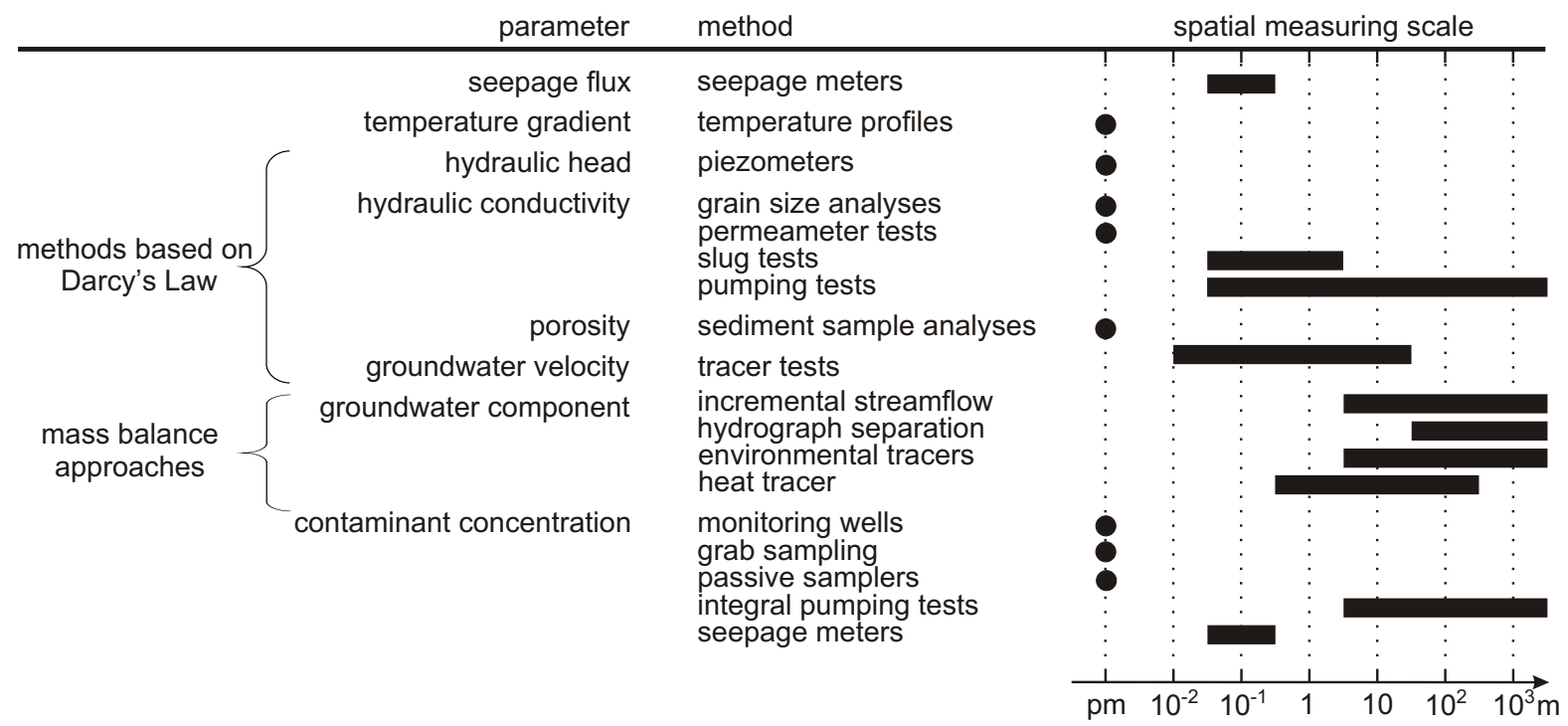

Fig. 1. Spatial measuring scales of the different methods to measure interactions between groundwater and surface water. The spatial scale is given as radius or distance of influence. Dots represent point measurements (pm).

methods constitutes a trade-off between resolution of heterogeneities and sampled volume (Rubin et al., 1999).

In general, most methods applied in the subsurface provide point estimates of the respective parameter, whereas most methods applied to the surface water represent larger sample volumes. Measurements of hydraulic head, grain size analysis, and permeameter tests are point measurements. In slug and bail tests and tracer tests, the portion of sampled aquifer volume is larger, on the scale of meters around the sample point. Pumping tests operate on the largest scale among the methods applied in the subsurface, typically on the scale of tens of meters up to kilometers. Measurements of the temperature gradient in the streambed provide point estimates of flux. Seepage meter measurements yield flux estimates over the diameter of the seepage pan, usually less than one meter. Incremental streamflow measurements result in groundwater discharge estimates averaged over the reach length between measurement transects, ranging from several meters to hundreds of meters. The same applies to environmental and heat tracer methods aiming at identifying the groundwater contribution to streamflow. Solute tracer methods for the estimation of transient storage also operate on the reach scale. Hydrograph separation delivers information on the groundwater discharge upstream of a gauging station and, therefore, enables the calculation of discharge rates averaged over the upstream length. Concerning contaminant concentration, grab sampling from piezometers or from the surface water, passive samplers and seepage meters provide point measurements of contaminant concentration, whereas integral pumping tests yield concentrations averaged over a large subsurface volume.
For measurements conducted in heterogeneous media, such as the subsurface, the measurement scale on which a selected technique operates may have a significant influence on the results, which has clearly been demonstrated for hydraulic conductivity in numerous studies. As Rovey and Cherkauer (1995) point out, hydraulic conductivity generally increases with test radius, because with a larger test radius the chance to encounter high-conductivity zones in a heterogeneous medium increases. Schulze-Makuch and Cherkauer (1998) found that hydraulic conductivity estimates increased during individual aquifer tests as the volume of aquifer impacted increased. Therefore, they concluded that scale-dependency of hydraulic conductivity is not related to the measurement method, but to the existence of high-conductivity zones within a low-conductivity matrix. Schulze-Makuch et al. (1999) observed no scaling effects for homogeneous media, whereas for heterogeneous media they found an empirical relation for the scaling behavior. The relationship is a function of the type of flow present (porous flow, fracture flow, conduit flow, doubleporosity media) and the degree of heterogeneity, associated with pore size and pore interconnectivity. The relationship was found to be valid up to an upper boundary value, representing the scale above which a medium can be considered quasi-homogeneous. In many of the test results included in the study by Schulze-Makuch et al. (1999), hydraulic conductivities obtained by pumping tests were close to the upper boundary.

The scale-dependency of measurements in heterogeneous media implies that even a dense grid of point measurements may deliver results that are considerably different from those obtained from larger-scale measurements, because the 


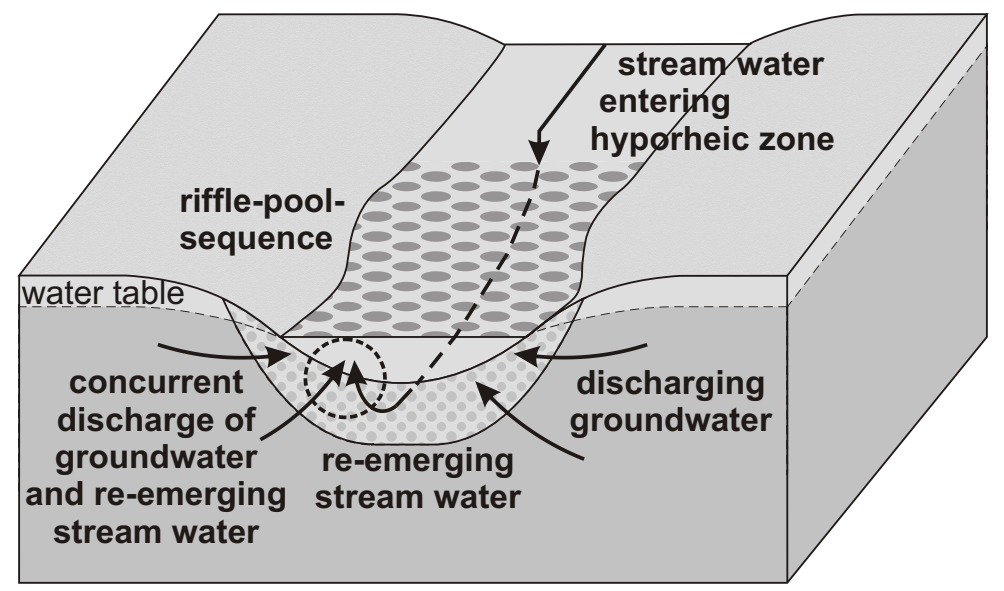

Fig. 2. Exchange flows between groundwater and surface water through the hyporheic zone at a riffle-pool-sequence (after Winter et al., 1998).

importance of small heterogeneities, such as narrow highconductivity zones, may be underestimated. A better representation of the local conditions including the effects of scale on measurement results can be achieved by conducting measurements at multiple scales within a single study site.

The various methods also differ in the time scale they represent. The majority of techniques deliver parameter estimates at a certain point in time. Only seepage meters and passive samplers collect water volume and contaminant mass, respectively, over a time period from hours to weeks and, thus, yield time-averaged fluxes. Hydrograph separation gives estimates of the groundwater contribution to streamflow averaged over the duration of the recorded hydrograph, typically from several years to decades. Automated sampling methods or data loggers, however, can help breaking down measurement time steps to intervals that allow for observations of temporal variations. In particular, parameters that can be measured simply using probes, such as pressure or temperature, are suitable for long-term monitoring.

\subsection{Groundwater discharge versus hyporheic exchange} flow

Exchange processes between streams and groundwater do not only comprise groundwater discharging to a stream or stream water infiltrating into the aquifer, but also include downwelling of stream water into the sediment and reemerging to the stream further downstream (Fig. 2). These small-scale exchange processes are driven by pressure variations caused by geomorphologic features such as poolriffle sequences, discontinuities in slope, or obstacles on the streambed (Thibodeaux and Boyle, 1987; Savant et al., 1987; Hutchinson and Webster, 1998). This implies that water discharging through the streambed into the stream can either be groundwater, or re-emerging surface water, or a mixture of both. Harvey and Bencala (1993) found that the gross in- flow (groundwater + subsurface flow) of water to their study stream exceeded the net inflow (groundwater only) by nearly twofold. Thus, methods to determine water flux in the shallow streambed, such as seepage meters or shallow streambed piezometers, may result in discharge rates that may not necessarily be attributed to groundwater discharge. Qualitative methods, such as heat or environmental tracers, may additionally be used to elucidate the origin of the water. Solute tracer methods based on the transient storage approach may help estimate the hyporheic flow component.

\subsection{Considerations for choosing appropriate methods}

The study goal plays a decisive role for the choice of appropriate methods to characterize groundwater - surface water interactions. The objective of the research project defines the required measurement scale which in turn constrains the possible methods. A regional assessment of water resources or the fate and transport of pollutants requires information on a large scale, requiring methods that represent a large sample volume, such as pumping tests or surface water methods. Equally, if the impact of groundwater discharge on surface water quality or vice versa is of concern, measurements on a large scale may be more appropriate. In contrast, investigations of the spatial variation of exchange processes and flow paths between groundwater and surface water require measurements that allow for high spatial resolutions, such as temperature profiles or piezometer methods. If temporal variations or trends are of concern, long-term monitoring of certain parameters may be required. Automated sampling methods and probes coupled with data loggers are most suitable for that purpose.

The choice between methods on a similar scale may be more of an operational character, considering factors such as accessibility of the study site, portability of the equipment, and financial and human resources, among others. Landon 
et al. (2001) compared instream methods for measuring hydraulic conductivity in sandy streambeds (in situ permeameter tests, seepage meters coupled with hydraulic head measurements, slug tests, grain size distribution) and found that the spatial variability of hydraulic conductivity was greater than the variability of hydraulic conductivity between different methods. They concluded that the method used may matter less than making enough measurements to characterize spatial variability.

Uncertainties inherent in the different techniques may be taken into account when selecting methods to study groundwater - surface water interactions. Measurements of hydraulic conductivity are generally characterized by high uncertainties, because hydraulic conductivity can vary over several orders of magnitude. Hence, flux estimates based on the Darcy equation are inherently inaccurate, which relates to the majority of methods applied in the aquifer and the transition zone. Hydrograph separation is based on the assumptions that stream discharge can be directly correlated to groundwater recharge. Several factors are neglected in this approach, such as evapotranspiration and bank storage, leading to considerable uncertainties (Halford and Mayer, 2000). Tracer-based hydrograph separation further assumes that preevent water and event water are clearly different in isotopic or chemical composition and that the composition is constant in space and time; both being conditions that are often not met (Genereux and Hopper, 1998). Similarly, environmental and heat tracer measurements in the surface water rely on clearly pronounced and stable differences between groundwater and surface water, incorporating some degree of uncertainty. Flux estimates based on temperature gradients in the streambed are calculated on the assumption of vertical flow beneath the stream, which may not be true in the vicinity of the river banks or because of influences of hyporheic water movement as described before. Furthermore, the influence of daily fluctuations in surface water temperature may create some error. Flux measurements made by conventional seepage meters may be influenced by the resistance of the collection system to streamflow (Murdoch and Kelly, 2003). The accuracy of contaminant concentrations from water samples is influenced by the handling of the samples and the detection sensitivity of the analysis methods. Passive flux meter measurements may further be affected by competitive sorption or rate-limited sorption, and by fluctuations in flow direction in case of long-term measurements. The evaluation of integral pumping tests requires information on aquifer properties which may already be uncertain. In conclusion, inaccuracies are inherent in all methods to determine interactions between groundwater and surface water, so that an analysis of uncertainties along with any measurement is indispensable.

Because of the limitations and uncertainties associated with the various methods, any attempt to characterize streamaquifer interactions may benefit from a multi-scale approach combining multiple techniques. For instance, flux measurements in the transition zone alone may not suffice to clearly identify the groundwater component, while isotope concentrations alone may also lead to misinterpretations. Also, integrating point measurements may not be a valid substitute for measurements on a larger scale due to the scale-effects of measurements in heterogeneous media. Therefore, measurements on multiple scales are recommended to characterize the various processes and include different factors controlling groundwater-surface water exchange. Furthermore, a combination of measurements of physical and chemical properties may help identify water sources and subsurface flow paths. For instance, Becker et al. (2004) combined current meter measurements with a stream temperature survey to both identify zones of groundwater discharge and calculate groundwater inflow to the stream; Constantz (1998) analysed diurnal variations in streamflow and stream temperature time series of four alpine streams to quantify interactions between stream and groundwater; James et al. (2000) combined temperature and the isotopes of $\mathrm{O}, \mathrm{H}, \mathrm{C}$, and noble gases to understand the pattern of groundwater flow; Harvey and Bencala (1993) used hydraulic head measurements and solute tracers injected into the stream and the subsurface to identify flow paths between stream channel and aquifer and to calculate exchange rates; Storey et al. (2003) used hydraulic head measurements, salt tracers injected into the subsurface, and temperature measurements in the stream and subsurface to trace the flow paths in the hyporheic zone; Ladouche et al. (2001) combined hydrological data, geochemical and isotopic tracers to identify the components and origin of stream water. An elaborate combination of methods can considerably reduce uncertainties and constrain flux estimates.

\section{Summary}

Measuring interactions between groundwater and surface water is an important component for integrated river basin management. Numerous methods exist to measure these interactions which are either applied in the aquifer, in the surface water, or in the transition zone itself.

The methods differ in resolution, sampled volume, and the time scales they represent. Often, the choice of methods constitutes a trade-off between resolution of heterogeneities and sampled subsurface volume. Furthermore, the measurement scale on which a selected technique operates may have a significant influence on the results, leading to differences between estimates obtained from a grid of point measurements and estimates obtained from large-scale techniques. Therefore, a better representation of the local conditions including the effects of scale on measurement results can be achieved by conducting measurements at multiple scales at a single study site.

Attention should be paid to distinguish between groundwater discharge and hyporheic exchange flow. Small-scale flow measurements in the shallow streambed may not suffice 
to make this distinction, so that additional measurements to identify the water source are recommended.

The study goal plays a decisive role in choosing appropriate methods. For regional investigations large-scale techniques may be more suitable, whereas process studies may require measurements which enable high resolution. All methods have their limitations and uncertainties. However, a multi-scale approach combining multiple techniques can considerably reduce uncertainties and constrain estimates of fluxes between groundwater and surface water.

Acknowledgements. This work was supported by the European Union FP6 Integrated Project AquaTerra (Project no. 505428) under the thematic priority "sustainable development, global change and ecosystems".

Edited by: P. Grathwohl

\section{References}

Alyamani, M. S. and Sen, Z.: Determination of Hydraulic Conductivity from Complete Grain-Size Distribution Curves, Ground Water, 31(4), 551-555, 1993.

Anderson, M. P.: Heat as a ground water tracer, Ground Water, 43(6), 951-968, 2005.

Bauer, S., Bayer-Raich, M., Holder, T., Kolesar, C., Müller, D., and Ptak, T.: Quantification of groundwater contamination in an urban area using integral pumping tests, J. Contam. Hydrol., 75, 183-213, 2004.

Baxter, C., Hauer, F. R., and Woessner, W. W.: Measuring groundwater-stream water exchange: New techniques for installing minipiezometers and estimating hydraulic conductivity, Trans. Am. Fisher. Society, 132(3), 493-502, 2003.

Bayer-Raich, M., Jarsjö, R., Liedl, R., Ptak, T., and Teutsch, G.: Average contaminant concentration and mass flow in aquifers from time-dependent pumping well data: Analytical framework, Water Resour. Res., 40, W08303, doi:10.1029/2004WR003095, 2004.

Becker, M. W., Georgian, T., Ambrose, H., Siniscalchi, J., and Fredrick, K.: Estimating flow and flux of ground water discharge using water temperature and velocity, J. Hydrol., 296(1-4), $221-$ 233, 2004

Bencala, K. E. and Walters, R. A.: Simulation of Solute Transport in a Mountain Pool-and-Riffle Stream: A Transient Storage Model, Water Resour. Res., 19(3), 718-724, 1983.

Beyer, W.: Zur Bestimmung der Wasserdurchlässigkeit von Kiesen und Sanden aus der Kornverteilungskurve, Wasserwirtschaft Wassertechnik, 14(6), 165-168, 1964.

Bopp, S., Weiß, H., Schirmer, M., Grathwohl, P., and Schirmer, K.: Passive Probennahme in Grund- und Oberflächenwasser EinÜberblick, Grundwasser 9(2), 109-118, 2004.

Bopp, S.: Development of a passive sampling device for combined chemical and toxicological long-term monitoring of groundwater, Dissertation, UFZ Centre for Environmental Research Leipzig-Halle / University of Rostock (Germany), 2004.

Borden, R. C., Daniel, R. A., Lebrun, L. E., and Davis, C. W.: Intrinsic biodegradation of MTBE and BTEX in a gasoline- contaminated aquifer, Water Resour. Res., 33(5), 1105-1115, 1997.

Bouwer, H. and Rice, R. C.: Slug Test for Determining Hydraulic Conductivity of Unconfined Aquifers with Completely Or Partially Penetrating Wells, Water Resour. Res., 12(3), 423-428, 1976.

Bredehoeft, J. D. and Papadopolus, I. S.: Rates of Vertical Groundwater Movement Estimated from the Earth's Thermal Profile, Water Resour. Res., 1(2), 325-328, 1965.

Brunke, M. and Gonser, T.: The ecological significance of exchange processes between rivers and groundwater, Freshwater Biol., 37, 1-33, 1997.

Butler, J. J.: The Design, Performance, and Analysis of Slug Tests, CRC Press LLC, Boca Raton, Fl, 1998.

Cardenas, M. B. and Zlotnik, V. A.: A simple constant-head injection test for streambed hydraulic conductivity estimation, Ground Water, 41(6), 867-871, 2003.

Carey, S. K. and Quinton, W. L.: Evaluating runoff generation during summer using hydrometric, stable isotope and hydrochemical methods in a discontinuous permafrost alpine catchment, Hydrol. Proc., 19(1), 95-114, 2005.

Carslaw, H. S. and Jaeger, J. C.: Conduction of Heat in Solids, Oxford University Press, New York, 1959.

Carter, R. W. and Davidian, J.: General procedures for gaging streams, U.S. Geol. Surv. Techniques of Water Resources Investigations, Book 3, Chapter A-6, 1968.

Chen, X. H.: Measurement of streambed hydraulic conductivity and its anisotropy, Environ. Geol., 39(12), 1317-1324, 2000.

Chow, V. T.: Handbook of applied hydrology, McGraw-Hill, New York, 1964.

Chow, V. T.: On the determination of transmissivity and storage coefficients from pumping test data, Trans. Am. Geophys. Union, 33, 397-404, 1952.

Christophersen, N. and Hooper, R. P.: Multivariate-Analysis of Stream Water Chemical Data - the Use of Principal ComponentsAnalysis for the End-Member Mixing Problem, Water Resour. Res., 28(1), 99-107, 1992.

Clark, I. D. and Fritz, P.: Environmental Isotopes in Hydrogeology, CRC Press, Boca Raton, 1997.

Conant, B., Cherry, J. A., and Gillham, R. W.: A PCE groundwater plume discharging to a river: influence of the streambed and near-river zone on contaminant distributions, J. Contam. Hydrol., 73(1-4), 249-279, 2004.

Conant, B.: Delineating and quantifying ground water discharge zones using streambed temperatures, Ground Water, 42(2), 243257, 2004.

Constantz, J. and Stonestrom, D.: Heat as a tracer of water movement near streams, in: Heat as a tool for studying the movement of ground water near streams, edited by: Stonestrom, D. and Constantz, J., U.S. Geol. Surv. Circular 1260, 2003.

Constantz, J., Stewart, A. E., Niswonger, R., and Sarma, L.: Analysis of temperature profiles for investigating stream losses beneath ephemeral channels, Water Resour. Res., 38(12), 1316, doi:10.1029/2001WR001221, 2002.

Constantz, J., Stonestrom, D., Stewart, A. E., Niswonger, R., and Smith, T. R.: Analysis of streambed temperatures in ephemeral channels to determine streamflow frequency and duration, Water Resour. Res., 37(2), 317-328, 2001.

Constantz, J.: Interaction between stream temperature, streamflow, 
and groundwater exchanges in Alpine streams, Water Resour. Res., 34(7), 1609-1615, 1998.

Cook, P. G. and Herczeg, A. L. (Eds): Environmental tracers in subsurface hydrology, Kluwer, Boston, 2000.

Cook, P. G., Favreau, G., Dighton, J. C., and Tickell, S.: Determining natural groundwater influx to a tropical river using radon, chlorofluorocarbons and ionic environmental tracers, J. Hydrol., 277(1-2), 74-88, 2003.

Cooper, H. H. and Jacob, C. E.: A generalized graphical method for evaluating formation constants and summarizing well-field history, Trans. Am. Geophys. Union, 27(4), 526-534, 1946.

Cooper, H. H., Papadopulos, I. S., and Bredehoeft, J. D.: Response to a finite-diameter well to an instantaneous charge of water, Water Resour. Res., 3(1), 263-269, 1967.

Coplen, T. B., Herczeg, A. L., and Barnes, C.: Isotope engineering - using stable isotopes of the water molecule to solve practical problems, in: Environmental tracers in subsurface hydrology, edited by: Cook, P. G. and Herczeg, A. L.: Kluwer, Boston, 2000.

D’Angelo, D. J., Webster, J. R., Gregory, S. V., and Meyer, J. L.: Transient Storage in Appalachian and Cascade mountain streams as related to hydraulic characteristics, J. N. Amer. Benthol. Soc., 12, 223-235, 1993.

Darcy, H. P. G.: Les fountaines publiques de la Ville de Dijon, Victon Dalmont, Paris, 1856.

Davie, T.: Fundamentals of Hydrology, Routledge, New York, 2002.

De Jonge, H. and Rothenberg, G.: New device and method for fluxproportional sampling of mobile solutes in soil and groundwater, Environ. Sci. Technol., 39(1), 274-282, 2005.

Domenico, P. A. and Schwartz, F. W.: Physical and Chemical Hydrogeology, 2nd ed., John Wiley \& Sons Inc., New York, 1998.

Elliott, A. H. and Brooks, N. H.: Transfer of nonsorbing solutes to a streambed with bed forms: Theory, Water Resour. Res., 33(1), 123-136, 1997.

Freeze, R. A. and Cherry, J. A.: Groundwater, Prentice Hall Inc., Upper Saddle River, 1979.

Genereux, D. P. and Hooper, R. P.: Oxygen and Hydrogen Isotopes in Rainfall-Runoff Studies, in: Isotope Tracers in Catchment Hydrology, edited by: Kendall, C. and McDonnell, J. J., Elsevier Science, Amsterdam, 1998.

Halford, K. J. and Mayer, G. C.: Problems associated with estimating ground water discharge and recharge from stream-discharge records, Ground Water, 38(3), 331-342, 2000.

Hannula, S. R., Esposito, K. J., Chermak, J. A., Runnells, D. D., Keith, D. C., and Hall, L. E.: Estimating ground water discharge by hydrograph separation, Ground Water, 41(3), 368-375, 2003.

Hart, D. R., Mulholland, P. J., Marzolf, E. R., DeAngelis, D. L., and Hendricks, S. P.: Relationships between hydraulic parameters in a small stream under varying flow and seasonal conditions, Hydrol. Proc., 13(10), 1497-1510, 1999.

Harvey, F. E., Lee, D. R., Rudolph, D. L., and Frape, S. K.: Locating groundwater discharge in large lakes using bottom sediment electrical conductivity mapping, Water Resour. Res., 33(11), 26092615, 1997.

Harvey, J. W. and Bencala, K. E.: The Effect of Streambed Topography on Surface-Subsurface Water Exchange in Mountain Catchments, Water Resour. Res., 29(1), 89-98, 1993.

Harvey, J. W. and Wagner, B. J.: Quantifying hydrologic interac- tions between streams and their subsurface hyporheic zones, in: Streams and Groundwaters, edited by: Jones, J. B. and Mulholland, P. J., Academic Press, San Diego, 9-10, 2000.

Hatfield, K., Annable, M., Cho, J., Rao, P. S. C., and Klammler, H.: A direct passive method for measuring water and contaminant fluxes in porous media, J. Contam. Hydrol., 75, 155-181, 2004.

Hazen, A.: Some Physical Properties of Sands and Gravels, Mass. State Board of Health, 24th Annual Report, 539-556. 1892.

Hinkle, S. R., Duff, J. H., Triska, F. J., Laenen, A., Gates, E. B., Bencala, K. E., Wentz, D. A., and Silva, S. R.: Linking hyporheic flow and nitrogen cycling near the Willamette River - a large river in Oregon, USA, J. Hydrol., 244(3-4), 157-180, 2001.

Hooper, R. P. and Shoemaker, C. A.: A comparison of chemical and isotopic hydrograph separation, Water Resour. Res., 22(10), 1444-1454, 1986.

Hornberger, G. M., Raffensperger, J. P., Wiberg, P. L., and Eshleman, K. N.: Elements of Physical Hydrology, The John Hopkins University Press, Baltimore, 1998.

Hutchinson, P. A. and Webster, I. T.: Solute Uptake in Aquatic Sediments due to Current-Obstacle Interactions, J. Environ. Eng., 124(5), 419-426, 1998.

Hvorslev, M. J.: Time lag and soil permeability in ground-water observations, U.S. Army Corps of Engineers, Waterways Exper. Sta. Bull, 36, 1-50, 1951.

Hyder, Z., Butler, J. J., Mcelwee, C. D., and Liu, W. Z.: Slug Tests in Partially Penetrating Wells, Water Resour. Res., 30(11), 29452957, 1994.

Hynes, H. B. N.: Groundwater and stream ecology, Hydrobiologia, 100, 93-99, 1983.

Isiorho, S. A. and Meyer, J. H.: The effects of bag type and meter size on seepage meter measurements, Ground Water, 37(3), 411413, 1999.

James, E. R., Manga, M., Rose, T. P., and Hudson, G. B.: The use of temperature and the isotopes of $\mathrm{O}, \mathrm{H}, \mathrm{C}$, and noble gases to determine the pattern and spatial extent of groundwater flow, J. Hydrol., 237(1-2), 100-112, 2000.

Kelly, S. E. and Murdoch, L. C.: Measuring the hydraulic conductivity of shallow submerged sediments, Ground Water, 41(4), 431-439, 2003.

Kendall, C. and Caldwell, E. A.: Fundamentals of Isotope Geochemistry, in: Isotope Tracers in Catchment Hydrology, edited by: Kendall, C. and McDonnell, J. J., Elsevier Science, Amsterdam, 1998.

Kendall, C. and McDonnell, J. J. (Eds): Isotope Tracers in Catchment Hydrology, Elsevier Science, Amsterdam, 1998.

Kilpatrick, F. A. and Cobb, E. D.: Measurement of discharge using tracers, U.S. Geol. Surv., Techniques of Water-Resources Investigations, Book 3, Chapter A-16, 1985.

Kilpatrick, F. A. and Schneider, V. R.: Use of flumes in measuring discharge, U.S. Geol. Surv., Techniques of Water-Resources Investigations, Book 3, Chapter A-14, 1983.

Kot, A., Zabiegala, B., and Namiesnik, J.: Passive sampling for long-term monitoring of organic pollutants in water, Trends Anal. Chem. 19, 446-459, 2000.

Kraemer, T. F.: Radium isotopes in Cayuga Lake, New York: Indicators of inflow and mixing processes, Limnol. Oceanogr., 50(1), 158-168, 2005.

Krupa, S. L., Belanger, T. V., Heck, H. H., Brock, J. T., and Jones, B. J.: Krupaseep-the next generation seepage meter, Interna- 
tional Coastal Symposium (ICS 98), Special Issue 26, 210-213, 1998.

Ladouche, B., Probst, A., Viville, D., Idir, S., Baque, D., Loubet, M., Probst, J. L., and Bariac, T.: Hydrograph separation using isotopic, chemical and hydrological approaches (Strengbach catchment, France), J. Hydrol., 242(3-4), 255-274, 2001.

Landon, M. K., Rus, D. L., and Harvey, F. E.: Comparison of instream methods for measuring hydraulic conductivity in sandy streambeds, Ground Water, 39(6), 870-885, 2001.

Laudon, H. and Slaymaker, O.: Hydrograph separation using stable isotopes, silica and electrical conductivity: an alpine example, J. Hydrol., 201(1-4), 82-101, 1997.

Lee, D. R.: Device for Measuring Seepage Flux in Lakes and Estuaries, Limnol. Oceanogr., 22(1), 140-147, 1977.

Lee, D. R. and Cherry, J. A.: A Field Exercise on Groundwater Flow Using Seepage Meters and Mini-Piezometers, J. Geol. Educ., 27, 6-10, 1978.

Libelo, E. L. and MacIntyre, W. G.: Effects Of Surface-Water Movement On Seepage-Meter Measurements Of Flow Through The Sediment-Water Interface, Hydrogeol. J., 2, 49-54, 1994.

Linsley, R. K., Kohler, M. A., and Paulhus, J. L. H.: Hydrology for Engineers, McGraw-Hill Book Company, London, 1988.

Mau, D. P. and Winter, T. C.: Estimating ground-water recharge from streamflow hydrographs for a small mountain watershed in a temperate humid climate, New Hampshire, USA, Ground Water, 35(2), 291-304, 1997.

McDonnell, J. J., Bonell, M., Stewart, M. K., and Pearce, A. J.: Deuterium variations in storm rainfall: implication for stream hydrograph separation, Water Resour. Res., 26(3), 455-458, 1990.

Moench, A. F.: Combining the Neuman and Boulton Models for Flow to a Well in an Unconfined Aquifer, Ground Water, 33(3), 378-384, 1995.

Morrice, J. A., Valett, H. M., Dahm, C. N., and Campana, M. E.: Alluvial characteristics, groundwater-surface water exchange and hydrological retention in headwater streams, Hydrol. Proc., 11(3), 253-267, 1997.

Murdoch, L. C. and Kelly, S. E.: Factors affecting the performance of conventional seepage meters, Water Resour. Res., 39(6), 1163 , doi:10.1029/2002WR001347, 2003.

Mutz, M. and Rohde, A.: Processes of Surface-Subsurface Water Exchange in a Low Energy Sand-Bed Stream, Int. Rev. Hydrobiol., 88(3-4), 290-303, 2003.

Namiesnik, J., Zabiegala, B., Kot-Wasik, A., Partyka, M., and Wasik, A.: Passive sampling and/or extraction techniques in environmental analysis: a review, Anal. Bioanal. Chem., 381, 279301, 2005

Negrel, P., Petelet-Giraud, E., Barbier, J., and Gautier, E.: Surface water-groundwater interactions in an alluvial plain: Chemical and isotopic systematics, J. Hydrol., 277(3-4), 248-267, 2003.

Neuman, S. P.: Analysis of Pumping Test Data from Anisotropic Unconfined Aquifers Considering Delayed Gravity Response, Water Resour. Res., 11(2), 329-342, 1975.

Paulsen, R. J., Smith, C. F., O'Rourke, D., and Wong, T. F.: Development and evaluation of an ultrasonic ground water seepage meter, Ground Water, 39(6), 904-911, 2001.

Pinder, G. F. and Jones, J. F.: Determination of the groundwater component of peak discharge from the chemistry of total runoff, Water Resour. Res., 5(2), 438-445, 1969.

Pitkin, S. E., Cherry, J. A., Ingleton, R. A., and Broholm, M.: Field demonstrations using the Waterloo ground water profiler, Ground Water Monit. Remediat., 19(2), 122-131, 1999.

Powell, R. M. and Puls, R. W.: Hitting the bull's-eye in groundwater sampling, Pollut. Eng., 29, 50-54, 1997.

Ptak, T., Schwarz, R., Holder, T., and Teutsch, G.: Ein neues integrales Verfahren zur Quantifizierung der Grundwasserimmission, Teil II: Numerische Lösung und Anwendung in Eppelheim, Grundwasser, 4, 176-183, 2000.

Rodgers, P., Soulsby, C., Petry, J., Malcolm, I., Gibbins, C., and Dunn, S.: Groundwater-surface-water interactions in a braided river: a tracer-based assessment, Hydrol. Proc., 18(7), 13151332, 2004.

Rosenberry, D. O. and Morin, R. H.: Use of an electromagnetic seepage meter to investigate temporal variability in lake seepage, Ground Water, 42(1), 68-77, 2004.

Rovey, C. W. and Cherkauer, D. S.: Scale Dependency of Hydraulic Conductivity Measurements, Ground Water, 33(5), 769780, 1995.

Rubin, Y., Hubbard, S. S., Wilson, A., and Cushey, M. A.: Aquifer Characterization, in: The Handbook of Groundwater Engineering, edited by: Delleur, J. W., CRC Press, Boca Raton, 1999.

Runkel, R. L., McKnight, D. M., and Rajaram, H.: Modeling hyporheic zone processes, Adv. Water Resour., 26(9), 901-905, 2003.

Runkel, R. L.: One-Dimensional Transport with Inflow and Storage (OTIS): A Solute Transport Model for Streams and Rivers, U.S. Geol. Surv. Water Resour. Invest. Rep., 98-4018, 1998.

Savant, S. A., Reible, D. D., and Thibodeaux, L. J.: Convective Transport within stable river sediments, Water Resour. Res., 23(9), 1763-1768, 1987.

Scanlon, B. R., Healy, R. W., and Cook, P. G.: Choosing appropriate techniques for quantifying groundwater recharge, Hydrogeol. J., 10(1), 18-39, 2002.

Schirmer, M., Bopp, S., and Schirmer, K.: Depth-specific passive groundwater sampling for chemical and toxicological analyses of contaminants, Zentralblatt für Geologie und Paläontologie Teil I, Heft 1/2, 167-174, ISBN 3-510-66040-4, 2005.

Schlichter, C. S.: Field Measurements of the Rate of Movement of Underground Waters., U.S. Geol. Surv. Water Supply Paper, 140, 1905.

Schmidt, C., Bayer-Raich, M., and Schirmer, M.: Characterization of spatial heterogeneity of groundwater-stream water interactions using multiple depth streambed temperature measurements at the reach scale, Hydrol. Earth Syst. Sci., 10, 849-859, 2006, http://www.hydrol-earth-syst-sci.net/10/849/2006/.

Schulze-Makuch, D. and Cherkauer, D. S.: Variations in hydraulic conductivity with scale of measurement during aquifer tests in heterogeneous, porous carbonate rocks, Hydrogeol. J., 6(2), 204 215, 1998.

Schulze-Makuch, D., Carlson, D. A., Cherkauer, D. S., and Malik, P.: Scale dependency of hydraulic conductivity in heterogeneous media, Ground Water, 37(6), 904-919, 1999.

Schwarz, R., Ptak, T., Holder, T., and Teutsch, G.: Groundwater risk assessment at contaminated sites: a new investigation approach, in: GQ '98 Groundwater Quality: Remediation and Protection, edited by: Herbert M. and Kovar K., IAHS Publication, 250, 68$71,1998$.

Schwoerbel, J.: Ueber die Lebensbedingungen und die Besiedlung des hyporheischen Lebensraumes, Archiv fuer Hydrobiologie, 
Suppl. 25, 182-214, 1961.

Shepherd, R. G.: Correlations of Permeability and Grain-Size, Ground Water, 27(5), 633-638, 1989.

Sholkovitz, E., Herbold, C., and Charette, M.: An automated dyedilution based seepage meter for the time-series measurement of submarine groundwater discharge, Limnol. Oceanogr. Methods 1, 16-28, 2003.

Silliman, S. E., Ramirez, J., and McCabe, R. L.: Quantifiying downflow through creek sediments using temperature time series: One-dimensional solution incorporating measured surface temperature, J. Hydrol., 167, 99-119, 1995.

Sophocleous, M.: Interactions between groundwater and surface water: the state of the science, Hydrogeol. J., 10, 52-67, 2002.

Springer, A. E., Petroutson, W. D., and Semmens, B. A.: Spatial and temporal variability of hydraulic conductivity in active reattachment bars of the Colorado River, Grand Canyon, Ground Water, 37(3), 338-344, 1999.

Stallman, S.: Steady one-dimensional fluid flow in a semi-infinite porous medium with sinusoidal surface temperature, J. Geophys. Res., 70(12), 2821-2827, 1965.

Stonestrom, D. A. and Constantz, J.: Using Temperature to Study Stream-Groundwater Exchanges, U. S. Geol. Surv. Fact Sheet, 2004-3010, 2004.

Storey, R. G., Howard, K. W. F., and Williams, D. D.: Factors controlling riffle-scale hyporheic exchange flows and their seasonal changes in a gaining stream: A three-dimensional groundwater flow model, Water Resour. Res., 39(2), 1034, doi:10.1029/2002WR001367, 2003.

Stuer-Lauridsen, F.: Review of passive accumulation devices for monitoring organic micropollutants in the aquatic environment, Environ. Pollut., 136, 503-524, 2005.

Suzuki, S.: Percolation measurements based on heat flow through soil with special reference to paddy fields, J. Geophys. Res., 65(9), 2883-2885, 1960.

Taniguchi, M. and Fukuo, Y.: Continuous Measurements of Groundwater Seepage Using An Automatic Seepage Meter, Ground Water, 31(4), 675-679, 1993.

Taniguchi, M., Turner, J. V., and Smith, A. J.: Evaluations of groundwater discharge rates from subsurface temperature in Cockburn Sound, Western Australia, Biogeochem., 66(1-2), 111-124, 2003
Terzaghi, K.: Erdbaumechanik auf bodenphysikalischer Grundlage, Deuticke, Wien, 1925.

Teutsch, G., Ptak, T., Schwarz, R., and Holder, T.: Ein neues integrales Verfahren zur Quantifizierung der Grundwasserimmission, Teil I: Beschreibung der Grundlagen, Grundwasser, 4, 170$175,2000$.

Theis, C. V.: The relation between the lowering of the piezometric surface and the rate and duration of discharge of a well using groundwater storage, Trans. Amer. Geophys. Union, 16, 519524, 1935.

Thibodeaux, L. J. and Boyle, J. D.: Bedform-generated convective transport in bottom sediments, Nature, 325, 341-343, 1987.

Todd, D. K. and Mays, L. W.: Groundwater Hydrology, Wiley, Hoboken, 2005.

Turcotte, D. L. and Schubert, G.: Geodynamics: Applications of Continuum Physics to Geological Problems, JohnWiley \& Sons, New York, 1982.

Vrana, B., Mills, G. A., Allan, I. J., Dominiak, E., Svensson, K., Knutsson, J., Morrison, G., and Greenwood, R.: Passive sampling techniques for monitoring pollutants in water, Trends Anal. Chem., 24(10), 845-866, 2005.

Winter, T. C., Harvey, J. W., Franke, O. L., and Alley, W. M.: Ground Water and Surface Water: A Single Resource, U.S. Geol. Surv. Circular 1139, 1998.

Woessner, W. W. and Sullivan, K. E.: Results of Seepage Meter and Mini-Piezometer Study, Lake Mead, Nevada, Ground Water, 22(5), 561-568, 1984.

Woessner, W. W.: Stream and fluvial plain ground water interactions: Rescaling hydrogeologic thought, Ground Water, 38(3), 423-429, 2000.

Wu, Y., Wen, X. and Zhang, Y.: Analysis of the exchange of groundwater and river water by using Radon-222 in the middle Heihe Basin of northwestern China, Environ. Geol., 45(5), 647-653, 2004.

Yehdeghoa, B., Rozanski, K., Zojer, H., and Stichler, W.: Interaction of dredging lakes with the adjacent groundwater field: an isotope study, J. Hydrol., 192(1-4), 247-270, 1997.

Zellweger, G. W.: Testing and Comparison of 4 Ionic Tracers to Measure Stream-Flow Loss by Multiple Tracer Injection, Hydrol. Proc., 8(2), 155-165, 1994. 